\title{
PENGENALAN PERMAINAN SAINS BAGI SISWA SDK TES KECAMATAN BIKOMI UTARA, TIMOR TENGAH UTARA
}

\author{
Vinsensia Ulia Rita Sila1), Hermina Manlea ${ }^{2)}$, Sefrinus.M. D. Kolo ${ }^{3)}$ \\ Program Studi Pendidikan Biologi, FIP, Universitas Timor, Indonesia1),2) \\ Program Studi Kimia, FST, Universitas Timor, Indonesia ${ }^{3)}$ \\ Pos-el: sefriunimor@gmail.com ${ }^{3)}$
}

\begin{abstract}
Abstrak
Pengabdian ini bertujuan untuk menciptakan, menimbulkan kesukaan, dan ketertarikan siswa terhadap pelajaran sains, mengenalkan beberapa macam alat sederhana dan penggunaannya, mengetahui dan melaksanakan praktikum fisika, kimia dan biologi sederhana yang bisa dilakukan dengan memanfaatkan alat dan bahan yang tersedia di SDK Tes.

Kegiatan pengabdian ini dilaksanakan di SDK Tes pada hari Rabu tanggal 16 Agustus 2017. Materi pengabdian berupa materi permainan sains, antara lain perbedaan tekanan udara, uangku terbakar uangku utuh, mengapung atau tidak mengapung, membuat magnet sederhana, memahami prinsip kayu (dayung), posisi air pada gelas besar terbalik, cangkang telur jauh lebih kuat dari yang terlihat, telur ajaib, kekuatan air, pembiasan cahaya, udara dan pembakaran, tes kerapatan.

Pelaksanaan demonstrasi tersebut dilakukan dengan menggunakan interaksi yang baik antara siswa dengan guru. Siswa tidak malu untuk bertanya dengan guru. Hal ini memudahkan siswa memecahkan masalah yang dihadapinya. Selain itu, guru tidak menggerutu atau memarahi siswa yang mengalami kegagalan dalam melakukan percobaan atau demonstrasi. Para siswa SDK Tes sangat antusias, aktif, interaktif dan tidak kaku dalam belajar IPA. Para guru SDK Tes mengenal praktikum sains (Fisika, Kimia dan Biologi) sederhana yang bisa dilakukan dengan memanfaatkan alat dan bahan yang tersedia di lingkungan sekitar.
\end{abstract}

Kata Kunci: Laboratorium IPA, Permainan Sains Sederhana, SDK Tes

\begin{abstract}
Based on our surveys and observations, we found that SDK Tes has the facilities in science laboratory which is complete such as a box of integrated instruments that is newly provided in the last three years. However, there was practical obstacle which
\end{abstract}


prominent that the teachers did not take advantage by using these instruments to create an active, creative and enjoyable learning process in the classroom. This results in the way students learn science, in which they did not experience and practice the science learning materials by themselves provided by the books. Based on this fact, it is important to hold a service activity about "The Introduction of Science Games for Students in SDK Tes, the district of Bikomi Utara, Timor Tengah Utara Regency" with the main aim to creating and attracting students' attention and interests towards science, building a perception that science is interesting and enjoyable, knowing the simple instruments and how to use it, and implementing the simple experiments for Physics, Chemistry and Biology by using the instruments provided in SDK Tes.

This service activity was held in SDK Tes on Wednesday, 16th August 2017. The content of this service activity was about the learning materials of science games such as the differenciation of air pressure, "My money is burnt, my money is okay", Floating and not Floating, Making simple magnets, Understanding the principle of wood (paddle), the position of water in a reverse big glass, the eggshell is stronger than we thought, the miracle egg, the power of water, the refraction of water, and the density.

The implementation of these demonstrations were held with good interaction between students and the teacher. Students were not shy in posing any questions for the teachers. This makes the students felt easier to solve the problems. Besides, teachers were not angry or got mad of students if they did not succed in conducting the experiments. The students in SDK Tes were enthusiastic, active, interative and more flexible in learning science. The teachers also took advantage in conducting simple experiments (Physics, Chemistry and Biology) by using the instruments provided in SDK Tes or its surrounding

Keywords: Science Laboratory, Science Simple Games, SDK Tes.

\section{PENDAHULUAN}

Peran serta semua elemen dalam pembangunan bangsa merupakan suatu wujud tanggung jawab moral yang harus dikerjakan untuk mencapai cita-cita luhur bangsa. Untuk itu, sangat dibutuhkan agen-agen pembangunan yang tidak bisa dilihat saja dari kuantitas, tetapi diperlukan adanya kualitas sumber daya manusia yang idealis dan progresif. Memasuki abad 21 ini, pendidikan mempunyai arah tujuan yang jelas yaitu memartabatkan manusia Indonesia di kancah internasional. Oleh karena itu, pernyataan di atas perlu kita jadikan spirit dalam membangun peradaban bangsa, sejalan dengan visi pendidikan nasional yaitu "Terwujudnya sistem pendidikan sebagai pranata sosial yang kuat dan berwibawa untuk memberdayakan semua warga negara Indonesia 
berkembang menjadi manusia berkualitas sehingga mampu dan proaktif menjawab tantangan zaman yang selalu berubah".

Menyadari bahwa pendidikan mempunyai peranan penting dan strategis dalam pembangunan bangsa, maka pemerintah terus bertekad memberikan perhatian yang besar pada pembangunan pendidikan. Melalui proses pembangunan pendidikan, kita hendaknya membangun manusia Indonesia seutuhnya menjadi subjek yang bermutu. Atas dasar itulah, langkah kita ke depan menjadi bagian penting yang menentukan perkembangan pendidikan di tanah air.

Kualitas pendidikan dipengaruhi oleh banyak faktor, antara lain tersedianya sarana prasarana pendidikan yang memadai dan sumber daya manusia pendidikan yang berkompeten (Hofstein \& Luneta, 2003). Keduanya merupakan komponen input yang sangat penting dalam mendukung kegiatan pembelajaran. Oleh karena itu, perlu dilakukan peningkatan baik dari segi kuantitas, kualitas, maupun sistem pengelolaannya. Salah satu sarana pendidikan yang berfungsi sebagai penunjang dalam pelaksanaan proses pembelajaran di sekolah, terutama yang berhubungan dengan kegiatan praktikum adalah Laboratorium IImu Pengetahuan Alam (IPA).

Dalam Permendiknas RI Nomor 24 Tahun 2017 disebutkan bahwa komponen fasilitas laboratorium IPA di SMP dan SMA meliputi (1) bangunan atau ruang laboratorium, (2) perabot, (3) peralatan pendidikan, (4) alat dan bahan percobaan, (5) media pendidikan, (6) bahan habis pakai, (7) perlengkapan lainnya. Pemanfaatan dan pengelolaan laboratorium IPA sebagai fasilitas sekolah harus memperhatikan faktor kondisi dan mutu fasilitas, karena kedua faktor tersebut dapat berpengaruh secara langsung terhadap proses pendidikan (Mahiruddin, 2008)

Salah satu masalah yang sering kali menjadi momok yang menakutkan dan mempengaruhi mental dan kepribadian anak-anak didik yaitu pelajaran MIPA. Banyak orang yang mendengar ilmu-ilmu sains yaitu Matematika, Fisika, Kimia, dan Biologi terkadang merasa takut dan jenuh ketika mengikuti pelajarannya. Hal ini diperlukan kreativitas guru-guru IPA agar pembelajaran IPA dibuat lebih menyenangkan dan efektif dalam penerapannya. Oleh karena itu, sebagai pendidik dalam bidang sains, para guru dituntut untuk membagi ilmu dan kreativitas yang sudah dimiliki dalam bentuk sosialisasi dan demo sains kepada siswa/l di sekolah dasar dan sekolah menengah

Berdasarkan survei dan observasi awal kami, diperoleh bahwa SDK Tes memiliki fasilitas laboratorium IPA yang lengkap dengan kit-kit praktikum yang masih baru dengan tahun pengadaan kurang lebih dari tiga tahun lalu. Akan tetapi kendala praktis 
yang didapat adalah para guru tidak menggunakan alat-alat tersebut untuk pembelajaran IPA yang aktif, kreatif dan menyenangkan sehingga para siswa tidak pernah belajar dengan mengalami dan mempraktikkan sendiri materi sains yang diketahui oleh mereka dari buku. Berdasarkan hal ini maka pengabdian mengenai"Pengenalan Permainan Sains bagi Siswa/I SDK Tes Kecamatan Bikomi Utara Kabupaten Timor Tengah Utara" ini menjadi penting untuk dilaksanakan.

Tujuan pengabdian ini adalah untuk 1) menciptakan, menimbulkan kesukaan dan ketertarikan siswa terhadap pelajaran sains bahwa'sains itu asik dan menarik", 2) mengenal beberapa macam alat sederhana dan penggunaannya, 3) mengetahui dan melaksanakan praktikum Fisika,Kkimia dan Biologi sederhana yang bisa dilakukan dengan memanfaatkan alat dan bahan yang tersedia di SDK Tes. Manfaat pengabdian ini adalah 1) para siswa SDK Tes mengetahui berbagai praktikum Fisika, Kimia dan Biologi sederhana yang bisa dilakukan dengan memanfaatkan alat dan bahan yang tersedia di sekolah dan alam sekitar, 2) para guru SDK Tes mendapat IImu baru mengenai jenis-jenis praktikum Fisika, Kimia dan Biologi sederhana yang bisa dilakukan dengan memanfaatkan alat dan bahan yang tersedia di sekolah dan alam sekitar

\section{METODE}

Kegiatan pengabdian ini dilaksanakan di SDK Tes pada hari Rabu tanggal 16 Agustus 2017 dengan metode praktikum atau permainan sains yang dijabarkan sesuai dengan materi praktikum yang disiapkan. Metode demonstrasi dilakukan dengan memberikan langkah-langkah kegiatan kepada siswa, siswa melakukan percobaan sesuai dengan langkah-langkah yang diberikan lalu didemonstrasikan yang didampingi oleh guru-guru sehingga terjadi interaksi yang baik antara guru dan siswa.

\section{HASIL DAN PEMBAHASAN}

\section{Hasil Penelitian}

Jumlah peserta yang mengikuti kegiatan pengabdian ini adalah 80 orang siswa dan 5 orang guru. Materi permainan sains yang digunakan adalah 12 materi yang dipraktikkan atau didemonstrasikan didepan para siswa di ruang aula SDK Tes. Para siswa dan guru kelas diikutsertakan untuk mencoba materi percobaan tersebut. Alat dan bahan disiapkan oleh tim pengabdi yang dibantu oleh mahasiswa Program Studi Pendidikan Biologi Unimor sebanyak 30 orang. Materi permainan sains dapat dilihat pada Tabel 1. 
Tabel 1: Materi Permainan Sains

\begin{tabular}{|c|l|}
\hline No & \multicolumn{1}{|c|}{ Nama Permainan Sains } \\
\hline 1. & Perbedaan tekanan udara \\
\hline 2. & Uangku Terbakar, uangku utuh \\
\hline 3. & Mengapung atau tidak mengapung \\
\hline 4. & Membuat magnet sederhana \\
\hline 5. & Memahami prinsip kayuh/ dayung \\
\hline 6. & Posisi air pada gelas terbalik besar terbalik \\
\hline 7. & Cangkang telur jauh lebih kuat dari yang terlihat \\
\hline 8. & Telur ajaib \\
\hline 9. & Kekuatan air \\
\hline 10. & Pembiasan cahaya \\
\hline 11. & Udara dan pembakaran \\
\hline 12. & Tes kerapatan \\
\hline
\end{tabular}

\section{Pembahasan}

Berdasarkan terminologinya, praktikum diartikan sebagai suatu rangkaian kegiatan yang memungkinkan siswa menerapkan keterampilan atau mempraktikkan sesuatu. Dalam pembelajaran IPA, sesuatu ini adalah proses-proses sains. Dengan kata lain, didalam kegiatan praktikum sangat dimungkinkan adanya penerapan beragam keterampilan proses sains sekaligus pengembangan sikap ilmiah yang mendukung proses perolehan pengetahuan (produk keilmuan) dalam diri siswa. Disinilah tampak betapa praktikum memiliki kedudukan yang amat penting dalam pembelajaran IPA. Namun, seberapa jauh sebenarnya urgensi praktikum dalam pembelajaran IPA?

Bukankah selama ini tanpa praktikum pun siswa juga sudah belajar dan memperoleh pengetahuan? Kita mungkin menganggap bahwa selama ini pembelajaran yang telah kita rancang dan laksanakan dengan sedikit atau bahkan tanpa ada kegiatan praktikumnya, telah cukup memberi pengetahuan pada siswa kita. 
Namun, dengan begitu kita telah mengenyampingkan kebutuhan pemberdayaan dan pengembangan aspek-aspek lain pada diri siswa. Selain itu disadari atau tidak, kita kerap memaksakan kehendak pada siswa untuk memahami suatu konsep atau teori yang sebenarnya sulit bagi mereka. Kita sering alpa pada kemampuan dasar mereka, dan memaksa mereka untuk memahami suatu materi yang tidak mudah dipahami secara langsung. Bahwa sebenarnya ada kesenjangan antara siswa dengan objek persoalan, dan tanggungjawab kita sebagai guru untuk bisa menjembatani kesenjangan itu dengan memilih strategi yang memungkinkan siswa berinteraksi dengan objek dan persoalan.

Sikap dan perilaku para guru/dosen/mahasiswa dalam kegiatan pengabdian ini antara lain: 1) memberikan langkah-langkah kegiatan kepada siswa, 2) menyediakan alat dan bahan cadangan, 3) mengusahakan siswa dapat berpartisipasi aktif, 4) mengusahakan semua siswa dapat melihat demonstrasi tersebut (apabila demonstrasi dilakukan oleh guru dan atau beberapa siswa), 5) tidak menggerutu/marah apabila percobaan tidak berhasil, 6) memberikan penghargaan kepada siswa yang berhasil melakukan percobaan melalui tepuk tangan, 7) bertanya seputar demonstrasi kepada siswa pada saat demonstrasi berlangsung( siswa diberi pertanyaan oleh guru tentang kesimpulan yang diperoleh setelah melakukan demonstrasi didepan siswa dan demonstrasi yang dilakukan oleh guru, 8) siswa diminta untuk melakukan demonstrasi, 9) mencatat hasil percobaan, 10) interaksi siswa dengan guru tidak kaku, 11) guru menekankan kepada pemahaman siswa

Hal-hal ini menunjukkan bahwa penggunaan metode demonstrasi sains atau permainan sains pada pembelajaran IPA dapat berjalan dengan baik. Siswa diberi langkah-langkah kegiatan. Hal ini akan menantang siswa untuk menemukan produk sains melalui percobaan yang dilakukan. Guru juga mengikutsertakan siswa dalam demonstrasi. Demonstrasi ini dilakukan setelah siswa melakukan percobaan. Berarti guru mengedepankan pemahaman siswa terhadap materi yang dipelajari. Tindakan guru tersebut menjadikan siswa memiliki pengalaman langsung. Hal ini sesuai dengan hakikat pembelajaran sains, yaitu membelajarkan siswa seoptimal mungkin untuk memenuhi atau mengeksplorasikan alam sekitar guna mendapatkan pengetahuan yang bermanfaat dalam kehidupannya.

Pelaksanaan demonstrasi dilakukan dengan menggunakan interaksi yang baik antara siswa dengan guru. Siswa tidak malu untuk bertanya dengan guru. Hal ini akan memudahkan siswa memecahkan masalah yang dihadapinya. Selain itu, guru tidak 
menggerutu atau memarahi siswa yang mengalami kegagalan dalam melakukan percobaan atau demonstrasi. Namun, guru memberikan bimbingan kepada siswa tersebut.

\section{SIMPULAN}

Kesimpulan yang diambil berdasarkan hasil pengabdian ini adalah 1) para siswa SDK Tes sangat antusias, aktif, interaktif dan tidak kaku dalam belajar IPA, 2) para guru SDK Tes mengenal praktikum sains (Fisika, Kimia dan Biologi) sederhana yang bisa dilakukan dengan memanfaatkan alat dan bahan yang tersedia di SDK Tes atau di alam sekitar.

\section{UCAPAN TERIMA KASIH}

Pelaksanaan kegiatan pengabdian ini didukung oleh berbagai pihak. Oleh karena itu, penulis mengucapkan terima kasih kepada LPPM Unimor yang telah memberi kesempatan kepada tim ini untuk melaksanakan pengabdian dengan pendanaan dari LPPM Universitas Timor. Ucapan terima kasih juga tim ini sampaikan kepada guru-guru dan siswa SDK Tes yang telah bersedia mengikuti kegiatan pengabdian ini dengan baik.

\section{DAFTAR PUSTAKA}

Biehle,J.T, MOtz, L.L \& West,S.S.1999. NSta Guide To Schoo/ Science Facilities, Eric.

Fraser,B.J \& Mcrobbie, C.J.1995. Science Laboratory Classroom Environments At School And Universities: A Cross-National Study*. Educational Research And Evalution, 1, 289-317.

Hamid, A.A.2011. Sistem Manajemen Laboratorium IPA. Makalah.Disampaikan dalam Pendidikan dan Pelatihan Manajemen Pengelolaan Laboratorium IPA SMP/MTS bagi Pengelola (Kepala/Laboran/Teknisi) Laboratorium IPA SMP/MTS di Jurusan Fisika FMIPA UNY.

Hanuscin,D.L.2007. The Use Of Specialized Laboratory Facilities For Science In Elementary School: A Call For Research. Journal Of Elementary Science Education, $19,59-64$.

Hofstein, A \& Lunetta, V.N.2004. The Laboratory In Science Education: Foundations For The Twenty-First Century. Science Education, 88, 28-54. 
Hofstein, A, Navon, O., Kipnis, M. \& Mamlok-Naaman, R. 2005. Developing Students' Ability To Ask More And Better Questions Resulting From Inquiry-Type Chemistry Laboratories. Journal Of Research In Science Teaching, 42, 791-806.

Luneta, H. 2003. The Laboratory In Science Education: Foundations For The Twenty-First Century. Science Education, 88, 28-54.

Mahiruddin. 2008. Pengaruh Fasilitas dan Kompetensi pengelola terhadap Efektivitas Manajemen Laboratorium IPA SMA di Kabupaten Konawe.

Manlea, H.2017. Evaluasi Pengelolaan Laboratorium IPA SMP dan SMA di Kabupaten Belu, TTU, TTS dan Malaka. Bio-Edu, 2, 3-5.

Motz, L.L., Biehle, J.T \& West, S.S. 2007. NSta Guide To Planning School Science Facilities, NSta Press.

Osborne, J. 2002. Science Without Literacy: A Ship Without A Sail? Cambridge Journal Of Education, 32, 203-218.

Sundari, R. 2008. Evaluasi Pemanfaatan Laboratorium dalam Pembelajaran Biologi di Madrasah Aliyah Negeri. Jurnal Penelitian dan Evaluasi Pendidikan, Nomor 2, Tahun Xii, 197-212. 